\title{
THE STATE OF SOIL ORGANIC MATTER IN DIFFERENT PHYSICAL FRACTIONS DEPEND ON LAND USE TYPE
}

\author{
Mirza TVICA ${ }^{1}$
}

UDK 631.417(497.6)

\begin{abstract}
Known fact is that arable soils compared with correspondent native soils differ in the state of soil organic matter (SOM) and that agricultural practices halved content of soil organic carbon in last decades. Further, soil structure or aggregation mediates many biological and chemical processes in soil and influence on protecting of SOM. The objectives of this paper is to analyze how the different land use (forest, grassland and arable soil) effects on quality and quantity of SOM in different physical fraction. In particular, it is important to determine what pool (physically separated fraction) of SOM is most sensitive on cultivation and what pool is more resistant to mineralization.

The research is carried out on two soil type with different texture, Pseudogley and Terra rossa, in condition of different climate and soil management. Two groups of SOM analysis are singled out: 1) quantify SOC and $\mathrm{N}$ storage, and $\delta^{13} \mathrm{C}$ by horizons; and 2) quantify the SOC and $\mathrm{N}$ in the following physically separated fractions of SOM: a) coarse and fine particulated organic matter (POM) density $<1.8 \mathrm{gcm}^{-3}$; b) occluded POM in stable microaggregates 53-250 $\mu \mathrm{m}$; and c) SOM in small microaggregates $<53 \mu \mathrm{m}$.
\end{abstract}

Keywords: soil organic matter, physical fractions, type of land use

\section{INTRODUCTION}

Quantitative and qualitative inventory of soil organic carbon (SOC) is one of the main fields of research in soil science, spatially after increasing interest for biogeochemical cycles of carbon. The type of land use is an important factor controlling soil organic matter (SOM) storage since it affects the amount and quality of litter input, the litter decomposition rates and the processes of organic matter stabilization in soils (Six et al., 2002a). When a forest soil is brought under cultivation, the SOC content start declining (in same time release of $\mathrm{CO}_{2}$ to the atmosphere), and the rate of declining depends upon climatic factors, soil type (structure and texture) and intensity of cultivation. Historically, agricultural ecosystems have lost more than $50 \mathrm{PgC}$ (Lal et al., 2004). Some of this carbon lost can be recovered through improved management, thereby

\footnotetext{
${ }^{1}$ Faculty of Agriculture and Food Science, University of Sarajevo, Institute of PAM, Zmaja od Bosne 8, 71000 Sarajevo, Bosnia and Herzegovina, mirzatvica@hotmail.com
} 
withdrawing atmospheric $\mathrm{CO}_{2}$. Enhancing SOC content is important to improving soil quality, reducing risks of pollution and contamination of natural waters, and decreasing net gaseous emissions to the atmosphere. By J. Six et al., (2002b), the relationship between soil physical characteristics and the ability of soils to stabilize SOM is a key element in understanding the sequestration of organic $\mathrm{C}$ in soils and to illuminate the effects of land use changes on soil organic matter storage. According to Six et al., (2002b), Christensen (1996) and Stevenson (1994) describes three main mechanisms of stabilization SOM: i) chemical stabilization as the result of a chemical or physical chemical linkage between SOM and silt and clay, ii) physical protection where aggregates physically protected SOM forming a physical barrier between the microbe and organic substrates, and iii) biochemical stabilization that implies the existence of components in the organic substrate which are more resistant to decomposition. There is still considerable uncertainty about the effects of different land use and soil management on organic carbon storage in soil (B. John et al., 2004).

Two approaches are used to determine the impact of land management on the storage of carbon: a) measuring the change in carbon content in soils under different management (Campbell et al., 1995, 1996; according to D. Curtin et al, 1998) and b) measuring the flux of $\mathrm{CO}_{2}$ from the soil and in the soil (Rochette et al., 1992; according to D. Curtin et al., 1998).

The objectives of this paper is to analyse how the type of land use, in the condition of different texture and soil management, affects on quality and quantity of SOM in different physical fraction and to identify SOC pools that preferentially stabilize SOC in the long term.

\section{MATERIALS AND METHODS}

The research was carried out on the two types of soils: i) Pseudogley (Albeluvisol stagnic) on diluvial clay from Sprečko polje in northern Bosnia, Tuzla vicinity, and ii) Terra rossa (Chromic Cambisol, Chr. Luvisol) from Dubrava plateau in Herzegovina, Mostar vicinity. Three soil profiles were opened per site, on arable land, grassland and forest. It was important that the land use types have a long constant history (at least several decades of permanent cropping or permanent grassland or permanent forest) and that within a site soil parent material and soil texture are identical. In Sprečko polje on Pseudoglay the arable land is on a large farm which was a big Agricultural Complex in state-owned, with silage corn and oat in rotation, grassland represented 17 years abandoned arable soil and the forest was consisting of oak (Quercus sp.) In Dubrava platou on Terra rossa, arable land is on a farm in private-owned, with cattle raising and agricultural production with 46 crops in rotation, and forest is degraded and consisting of oak (Quercuspubescens) and ash (Fraxinusornus). On both plots on arable land was applicated manure, and in Tuzla in arable land and grassland were calcification (liming) done. 
In Tuzla (Pseudoglay), the climate is temperate continental. Average precipitation is $923 \mathrm{~mm}$ yearly, and average yearly temperature $10.2^{\circ} \mathrm{C}$. Mostar vicinity (Terra rossa) have a Mediterranean climate. Average precipitation is 1,459 $\mathrm{mm}$ yearly, and average yearly temperature $15^{\circ} \mathrm{C}$. Despite high precipitations mediterranean climate have arid characteristic rather than humid, because season (periodical) percipitations. Very important role on soil process have strong and dry wind "bura" which draying soil surface and take away small particles fine soil (wind erosion).

A soil profile samples has taken from the horizons (4 horizons per profile). Disturbed soil samples, which represents the horizons ( 3 replicates per horizon) have sieved $<2$ $\mathrm{mm}$ (remove all stones and all plant residues $>2 \mathrm{~mm}$ ), and then the sample has split in two parts: i) milled subsample, are used for analyses of total SOC and $\mathrm{N}$ in $\mathrm{CN}$ elementary analyzer; and ii) $2 \mathrm{~mm}$ sieved sample are used for analyses of $\mathrm{pH}, \mathrm{CEC}$ (repeated washing of the sample with $\mathrm{NH}_{4} \mathrm{Cl}, \mathrm{pH}$ at the start of washing is 4.6), and finally for physical fractionation and quantification off and $\mathrm{N}_{\text {fr }}$ in different soil physical fractions (density fractions and particle size fractions). Undisturbed samples in Kopezcky rings $\mathrm{V}=100 \mathrm{~cm}^{3}$, (3 replicates per horizon) are used to determine soil bulk density necessary to determine SOC stocks. At the forest plots the organic layer has to be sampled ( $\mathrm{n}=3$, and $25 \times 25 \mathrm{~cm}$ plots) to determine $\mathrm{SOC}$ and $\mathrm{N}$ stocks of the forest floor.

The research strategy adopted was to compare, in the same soil unit, plots with different land use (arable soil with conventional tillage, and native soils under grassland and forest) and to evaluate the long term impact of cultivation on SOM stocks in the soils. Three group objectives are singled out:

- quantification of total SOC and $\mathrm{N}$ and the analysis $\mathrm{C} / \mathrm{N}$ and $\delta{ }^{13} \mathrm{C}$ per horizons until 10 and $30 \mathrm{~cm}$ depth, as an indicator of the impact anthropogenisation;

- The main work on Institute of Soil Science and Forest Nutrition in Goettingen was the physical fractionation of the soil organic matter pools by modified method Six et al. (2002b) (density fractions and particle size fractions) in $2 \mathrm{~mm}$ sieved samples taken from $10 \mathrm{~cm}$ topsoil. That means to quantify the SOC and $\mathrm{N}$ in the following five physically separated fractions of SOM:

- three size fraction of light particulated organic matter (POM) density $<1.8 \mathrm{gcm}^{3}$ : free light fractions, coarse $>250 \mu \mathrm{m}$ (cPOM) and fine $53-250 \mu \mathrm{m}$ (fPOM) which are unprotected from decomposition, and occluded/intra POM which is physically protected in stable microaggregates 53-250 $\mu \mathrm{m}$ (iPOM). Fractionation of particulated organic matter (POM) were done on the basis floating in sodium polytungstate (SPT) specific gravity of $1.8 \mathrm{gcm}^{-3}$, 
- two fraction heavy SOM chemically protected by associated with silt and clay in small microaggregates $(<53 \mu \mathrm{m})$ density $>1.8 \mathrm{~g} \mathrm{~cm}^{-3}$ : SOM associated with free silt and clays (f silt+clay) separated after breaking macroaggregates, and occluded (intra) SOM associated with silt and clays physically protected in small microaggregates $<53 \mu \mathrm{m}$ (and silt+clay), separated after breaking microaggregates;

- discussion of affects soil texture and soil management on the storage soil organic carbon.

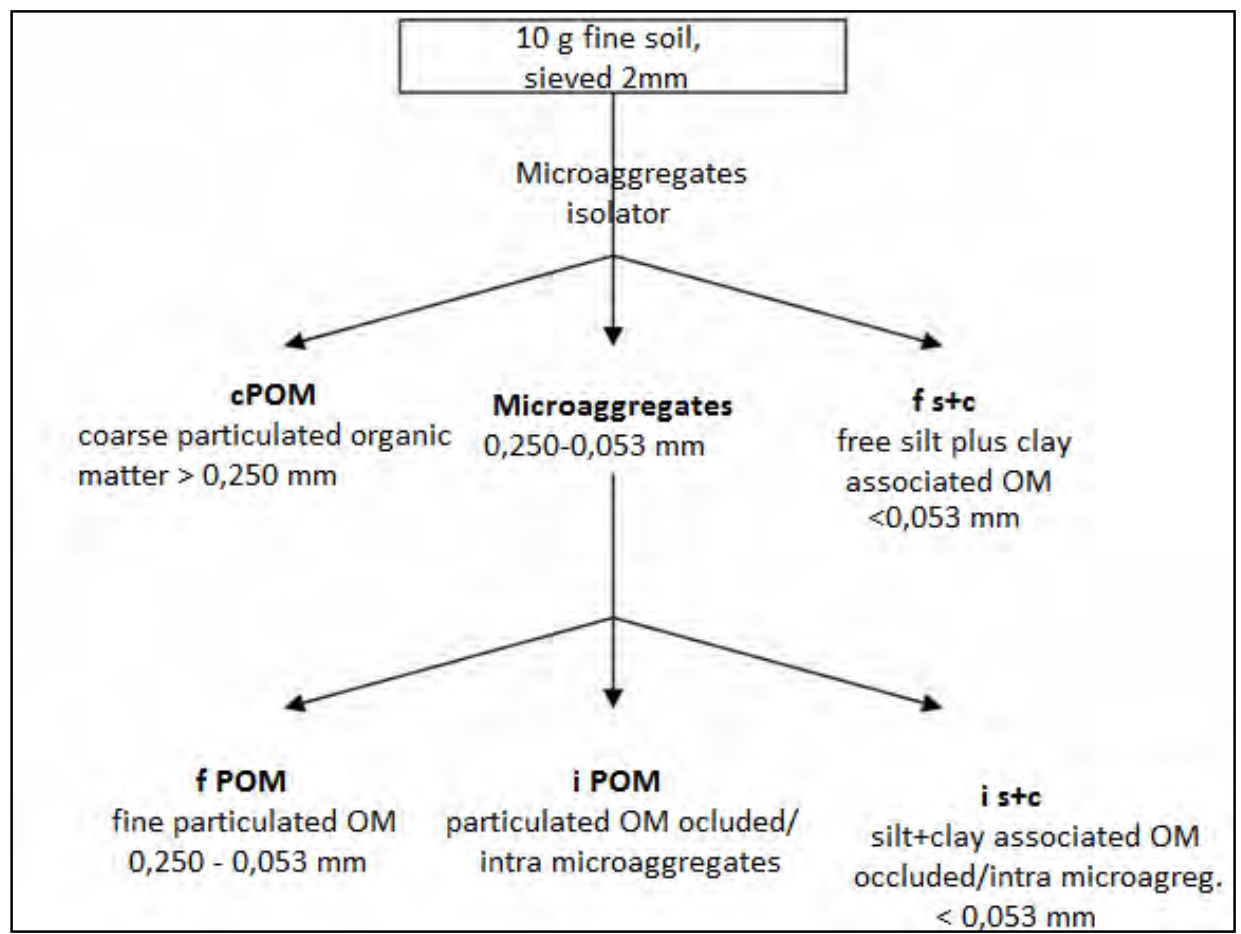

Figure 1. Scheme of fractionation 


\section{RESULTS}

Table 1. Physical and chemical properties $2 \mathrm{~mm}$ sieved samples: Texture, Bulk density (BD), $\mathrm{pH}$ (1M KCl), Cation exchange capacity (CEC), Base saturation (BS): $\mathrm{Ca}^{2+}, \mathrm{Mg}^{2+}, \mathrm{Na}^{+}$and $\mathrm{K}^{+}$in $\mathrm{CEC}$, Soil organic carbon (SOC),

Nitrogen $(\mathrm{N}), \mathrm{C} / \mathrm{N}$ ratio and $\delta^{13} \mathrm{C}$ under different type of the land use

\begin{tabular}{|c|c|c|c|c|c|c|c|c|c|c|c|c|c|}
\hline 1 & 2 & 3 & 4 & 5 & 6 & 7 & 8 & 9 & 10 & 11 & 12 & 13 & 14 \\
\hline 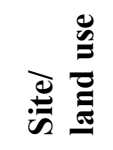 & 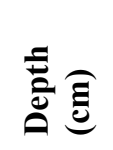 & $\vec{\Xi} e^{e}$ & 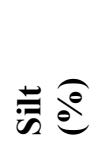 & 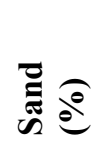 & 苗 & 플 & U & की & $u \partial^{0}$ & Z $e^{e}$ & ○ & $z_{0}^{Z}$ & $\underbrace{0}_{0}$ \\
\hline \multicolumn{14}{|c|}{ Pseudoglay/Albeluvisol (stagnic) } \\
\hline \multirow{4}{*}{$\underset{⿱ ⺌}{\frac{0}{2}}$} & $0-12$ & 25.6 & 45.2 & 29.2 & 1.47 & 3.7 & 6.5 & 61.7 & 1.24 & 0.12 & 2.18 & 10.1 & -25.01 \\
\hline & $12-30$ & 25.6 & 44.5 & 29.9 & 1.45 & 3.7 & 6.5 & 60.8 & 1.16 & 0.12 & 3.03 & 9.8 & -24.82 \\
\hline & $30-52$ & 24.8 & 47.5 & 27.7 & 1.54 & 3.6 & 6.6 & 59.6 & 0.99 & 0.10 & 3.35 & 9.6 & -24.93 \\
\hline & $52-99$ & 41.6 & 35.9 & 22.5 & 1.57 & 3.3 & 15.6 & 70.3 & 0.27 & 0.05 & 2.03 & 5.7 & -25.40 \\
\hline \multirow{4}{*}{ 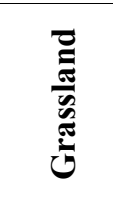 } & $0-15$ & 20.8 & 29.7 & 49.5 & 1.46 & 3.9 & 6.7 & 74.5 & 2.12 & 0.20 & 4.72 & 10.8 & -26.10 \\
\hline & $15-30$ & 21.2 & 30.1 & 48.7 & 1.30 & 3.9 & 6.1 & 71.6 & 1.76 & 0.16 & 3.42 & 11.1 & -26.19 \\
\hline & $30-50$ & 24.8 & 28.4 & 46.8 & 1.51 & 3.5 & 6.3 & 45.7 & 0.79 & 0.08 & 2.38 & 9.7 & -26.25 \\
\hline & $50-99$ & 40.4 & 18.8 & 40.8 & 1.47 & 3.2 & 13.8 & 53.0 & 0.35 & 0.05 & 2.57 & 6.7 & -25.68 \\
\hline \multirow{5}{*}{$\begin{array}{l}\vec{v} \\
\dot{0} \\
\dot{0} \\
\dot{1}\end{array}$} & $\mathrm{O}_{\mathrm{L}}$ & & & & & & & & 17.7 & 1.11 & 2.20 & 16.0 & -27.90 \\
\hline & $0-15$ & 20.4 & 45.5 & 34.1 & 1.19 & 3.5 & 6.1 & 14.7 & 2.49 & 0.21 & 4.42 & 11.7 & -27.39 \\
\hline & $15-30$ & 18.8 & 44.1 & 37.1 & 1.24 & 3.5 & 4.9 & 24.3 & 0.98 & 0.09 & 1.80 & 10.7 & -27.18 \\
\hline & $30-50$ & 24.4 & 43.1 & 32.5 & 1.58 & 3.3 & 8.9 & 54.4 & 0.29 & 0.05 & 0.90 & 5.5 & $-25.95^{*}$ \\
\hline & $50-99$ & 39.2 & 33.2 & 27.6 & 1.53 & 3.3 & 16.1 & 74.3 & 0.25 & 0.05 & 1.88 & 4.7 & -25.46 \\
\hline
\end{tabular}




\begin{tabular}{|c|c|c|c|c|c|c|c|c|c|c|c|c|c|}
\hline 1 & 2 & 3 & 4 & 5 & 6 & 7 & 8 & 9 & 10 & 11 & 12 & 13 & 14 \\
\hline \multicolumn{14}{|c|}{ Terra rossa /Chromic Cambisol } \\
\hline \multirow{4}{*}{$\begin{array}{l}\bar{\Xi} \\
\bar{\Xi} \\
\frac{0}{0} \\
\frac{\pi}{3}\end{array}$} & $0-13$ & 27.6 & 32.7 & 39.7 & 1.36 & 4.2 & 10.1 & 95.7 & 1.51 & 0.15 & 2.66 & 10.2 & -25.42 \\
\hline & $13-23$ & 28.0 & 31.7 & 40.3 & 1.25 & 4.3 & 9.8 & 97.1 & 1.47 & 0.14 & 1.84 & 10.4 & -25.33 \\
\hline & $23-47$ & 43.2 & 34.6 & 22.2 & 1.52 & 4.7 & 10.4 & 98.9 & 1.21 & 0.12 & 4.41 & 9.8 & -23.62 \\
\hline & $47-78$ & 39.6 & 33.4 & 27.0 & 1.54 & 4.7 & 12.8 & 99.5 & 1.25 & 0.12 & 5.99 & 10.5 & -24.11 \\
\hline \multirow{4}{*}{ 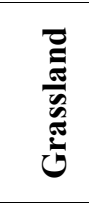 } & $0-10$ & 31.6 & 37.4 & 31.0 & 1.31 & 4.7 & 12.0 & 98.3 & 2.05 & 0.18 & 2.69 & 11.6 & -23.74 \\
\hline & $10-20$ & 39.2 & 27.3 & 33.5 & 1.46 & 4.5 & 10.4 & 97.6 & 1.26 & 0.12 & 1.84 & 10.7 & -22.95 \\
\hline & $20-40$ & 46.0 & 22.4 & 31.6 & 1.52 & 4.4 & 12.0 & 97.4 & 0.82 & 0.09 & 2.50 & 9.3 & -22.64 \\
\hline & $40-78$ & 56.4 & 20.0 & 23.6 & 1.49 & 4.6 & 17.8 & 99.3 & 0.63 & 0.09 & 3.55 & 7.3 & -22.42 \\
\hline \multirow{5}{*}{$\begin{array}{l}\vec{v} \\
\stackrel{0}{0} \\
\dot{0} \\
\dot{x}\end{array}$} & $\mathrm{O}_{\mathrm{L}}$ & & & & & & & & 19.1 & 0.92 & 0.32 & 20.8 & -26.68 \\
\hline & $0-11$ & 33.2 & 44.4 & 22.4 & 1.27 & 4.6 & 12.9 & 96.6 & 2.63 & 0.22 & 3.67 & 11.7 & -26.21 \\
\hline & $11-23$ & 37.6 & 38.0 & 24.4 & 1.38 & 4.2 & 10.0 & 88.4 & 1.65 & 0.15 & 2.75 & 10.7 & -24.70 \\
\hline & $23-38$ & 44.0 & 26.5 & 29.5 & 1.43 & 4.1 & 9.9 & 88.4 & 0.98 & 0.10 & 2.10 & 9.6 & -23.36 \\
\hline & $38-78$ & 43.6 & 29.5 & 26.9 & 1.48 & 4.1 & 10.5 & 89.8 & 0.63 & 0.07 & 3.70 & 8.3 & -23.30 \\
\hline
\end{tabular}

* signal less than $300 \mathrm{mV}$ results with uncertain results 
Pseudogley has a loam soil texture and Terra rossa clayey-loam texture (US Soil Taxonomy). According by Schefer-Schactschabel ( $\mathrm{pH}$ in $1 \mathrm{M} \mathrm{KCl}$ ) Pseudoglay has a very strong acidity $\mathrm{pH}$ and Terra rossa strong acidity. Furthermore, a rate of decomposition SOM increase throughout the soil profile. Data shows that upper layers of Terra rossa contains the higher values of CEC $\left(10-13 \mathrm{cmol}_{+} \mathrm{kg}^{-1}\right)$ as well as to impermeable clayey horizon in Pseudoglay. In Terra rossa total percent base saturation are in range 88.4-99.3\%. Lowest values of CEC are recorded in topsoil in pseudoglay in forest where recorded total percent base saturation less then is $50 \%$. In arable land and grassland on Pseudoglay where liming is made, records show higher values of total percent base saturation $(60-70 \%)$ than in forest.

Depend of the type of land use examined soils has been tested by the analysis of the complete $\mathrm{C}$ storage in $\mathrm{kg} \mathrm{m}^{-2}$ within $10 \mathrm{~cm}$ and $30 \mathrm{~cm}$ of depth.

Table 2. SOC storage within 10 and $30 \mathrm{~cm}$

\begin{tabular}{ccccccc}
\hline \multirow{2}{*}{$\begin{array}{c}\text { Depth } \\
\text { (cm) }\end{array}$} & \multicolumn{5}{c}{ SOC storage $\mathbf{( k g ~ m}^{-2}$ ) } \\
& Arable & Greudogley & \multicolumn{3}{c}{ Terra rossa } \\
\hline \hline within $\mathbf{1 0 ~} \mathbf{~ m}$ & 1.82 & 3.15 & 2.95 & 2.04 & 2.70 & 3.34 \\
\hline within $\mathbf{3 0} \mathbf{~ c m}$ & 5.21 & 8.14 & 8.42 & 5.78 & 5.78 & 7.71 \\
\hline
\end{tabular}

The SOC stock to $10 \mathrm{~cm}$ depth in Pseudoglay in mineral soil is greater in grassland than in the forest, which is in accordance with the suggestions of Collins et al., 2000, and Kononova, 1996 (according to J.Six et al., 2002b) that grassland have a highest potential for storage SOC due to their higher base saturation, as is the case in this soil.

SOC storage in $\mathrm{kg} \mathrm{m}^{-2}$ within $30 \mathrm{~cm}$ of depth is a good indicator of the impact cultivation on the SOC content. The average difference in SOC storage within $30 \mathrm{~cm}$ between forest and agricultural soils is $2.58 \mathrm{~kg} \mathrm{~m}^{-2}$ for both soils. Pseudogley makes the biggest proportion, with $3.21 \mathrm{~kg} \mathrm{~m}^{-2}$ more SOC in forest than in arable soil.

This analysis showed too, that natural soils on Pseudogley (grassland which is converted arable land and forest) have a higher content of organic carbon than natural soils of the Terra Rossa. Probably the most effective way of restoring the stock of carbon in cultivated soils is the restoration and maintenance of perennial vegetation (Bruce et al., 1998). However, in Terra rossa on the cultivable land were found higher content SOC than in arable land on Pseudoglay and the same storage of SOC as well as on the nearby grassland. The level of carbon in natural soils reflects the balance of the input $\mathrm{C}$ and loss of $\mathrm{C}$ under natural conditions, but in any case does not represent the upper limit of the carbon content of the soil (J. Six et al., 2002a). 
It is interesting to compare the results from Pseudoglay in Tuzla with the research John et al. (2004) at Stagnic luvisol (silty loam) in Rotthalmuenster (mean annual rainfall of $886 \mathrm{~mm}$ and a temperature of $8.7^{\circ} \mathrm{C}$, spruce forests)

Table 3. SOC storage $\left(\mathrm{kg} \mathrm{m}^{-2}\right)$ whit in $30 \mathrm{~cm}$ in Tuzla and Rotthalmuenster

\begin{tabular}{lccc}
\hline & Arable land & Grassland & $\begin{array}{c}\text { Forest } \\
\text { (mineral soil +O) }\end{array}$ \\
\hline Stagnic Albeluvisol/Psudoglay,Tuzla & 5,211 & 8,142 & $6,220+2,200$ \\
\hline Stagnic luvisol, Rotthalmuenster & 5,269 & 6,006 & $4,886+4,108$ \\
\hline
\end{tabular}

Results of SOC stocks in the arable land for both sites are equal, while in the natural soil under meadow in Tuzla have accumulated more organic carbon than inRotthalmuenster. Furthemor, in the mineral soil in oak forest in Tuzla were found larger stocks SOC, while in Rotthalmuenster the $\mathrm{O}$ horizon in spruce forest have a larger SOC stocks.

Table 4. Physical fraction: concentration soorganic carbon $(\mathrm{C})$ and nitrogen $(\mathrm{N})$, ratio $\mathrm{C} / \mathrm{N}$, storage of $\mathrm{C}$ in fractions $\mathrm{gC}_{\mathrm{fr}} \mathrm{m}^{-2}$, yield $\mathrm{C}_{\mathrm{fr}}\left(\mathrm{gm}^{-2}\right)$ in total SOC $\left(\mathrm{gm}^{-2}\right.$ within $10 \mathrm{~cm}$ depth), storage of $\mathrm{C}$ in fractions in $\mathrm{gC}_{\mathrm{fr}} \mathrm{kg}^{-1}$ soil

\begin{tabular}{|c|c|c|c|c|c|c|c|}
\hline 1 & 2 & 3 & 4 & 5 & 6 & 7 & 8 \\
\hline $\begin{array}{c}\text { Site/land } \\
\text { use }\end{array}$ & $\begin{array}{l}\text { Physical } \\
\text { fraction }\end{array}$ & $\begin{array}{l}\mathrm{C}_{\mathrm{fr}} \\
\% \\
\end{array}$ & $\begin{array}{c}\mathrm{N}_{\mathrm{fr}} \\
\%\end{array}$ & $\mathbf{C}_{\mathrm{fr}} / \mathbf{N}_{\mathrm{fr}}$ & $\mathrm{gC}_{\mathrm{fr}} \mathrm{m}^{-2}$ & $\begin{array}{c}\text { Yield (\%) } \\
\mathrm{C}_{\mathrm{fr}} \text { in } \mathrm{C}_{\mathrm{t}}\end{array}$ & $\begin{array}{c}\mathbf{C}_{\mathrm{fr}} \\
\mathrm{gC}_{\mathrm{fr}} \mathrm{kg}^{-1} \\
\end{array}$ \\
\hline \multicolumn{8}{|c|}{ Pseudoglay/Stagnic Albeluvisol } \\
\hline \multirow{5}{*}{ 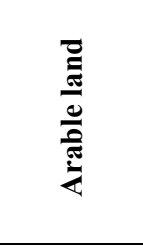 } & c POM & 32.45 & 1.52 & 21.41 & 80 & 4.39 & 0.55 \\
\hline & fPOM & 26.15 & 1.50 & 17.42 & 58 & 3.18 & 0.39 \\
\hline & i POM & 19.8 & 1.31 & 15.17 & 59 & 3.24 & 0.40 \\
\hline & i silt + clay & 1.28 & 0.15 & 8.59 & 477 & 26.19 & 3.25 \\
\hline & f silt + clay & 1.02 & 0.12 & 8.72 & 944 & 51.89 & 6.45 \\
\hline \multirow{5}{*}{ 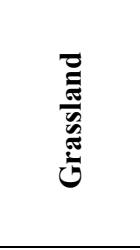 } & c POM & 30.39 & 1.81 & 17.01 & 183 & 5.82 & 1.25 \\
\hline & f POM & 27.47 & 1.85 & 14.87 & 126 & 4.00 & 0.87 \\
\hline & i POM & 25.12 & 1.79 & 14.12 & 195 & 6.19 & 1.34 \\
\hline & i silt + clay & 2.79 & 0.28 & 9.84 & 695 & 22.05 & 4.74 \\
\hline & f silt + clay & 1.54 & 0.17 & 9.25 & 1.587 & 50.39 & 10.87 \\
\hline \multirow{5}{*}{ 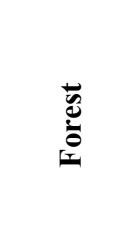 } & c POM & 34.18 & 1.24 & 27.55 & 157 & 5.32 & 1.32 \\
\hline & f POM & 27.64 & 1.42 & 19.27 & 53 & 1.81 & 0.45 \\
\hline & i POM & 23.43 & 1.46 & 16.1 & 119 & 4.03 & 1.01 \\
\hline & i silt + clay & 3.05 & 0.31 & 9.9 & 767 & 25.99 & 6.53 \\
\hline & f silt + clay & 2.07 & 0.21 & 10.04 & 1.555 & 52.71 & 13.04 \\
\hline
\end{tabular}




\begin{tabular}{|c|c|c|c|c|c|c|c|}
\hline 1 & 2 & 3 & 4 & 5 & 6 & 7 & 8 \\
\hline \multicolumn{8}{|c|}{ Terra rossa/Chromic Cambisol } \\
\hline \multirow{5}{*}{ 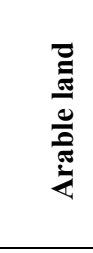 } & c POM & 27.81 & 1.60 & 17.43 & 103 & 5.05 & 0.76 \\
\hline & $\mathrm{fPOM}$ & 27.02 & 1.47 & 18.35 & 88 & 4.30 & 0.65 \\
\hline & i POM & 30.55 & 1.78 & 17.1 & 120 & 5.89 & 0.89 \\
\hline & i silt + clay & 1.49 & 0.15 & 8.24 & 661 & 32.40 & 5.11 \\
\hline & f silt + clay & 1.43 & 0.16 & 9.14 & 973 & 47.71 & 7.19 \\
\hline \multirow{5}{*}{ 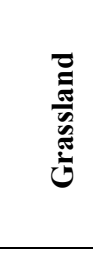 } & c POM & 27.61 & 1.10 & 25.32 & 148 & 5.49 & 1.12 \\
\hline & $\mathrm{fPOM}$ & 19.02 & 0.99 & 19.16 & 99 & 3.67 & 0.75 \\
\hline & i POM & 30.85 & 1.45 & 21.31 & 109 & 4.02 & 0.83 \\
\hline & i silt + clay & 2.11 & 0.23 & 9.14 & 1.146 & 42.43 & 8.70 \\
\hline & $\mathrm{s}$ silt + clay & 1.86 & 0.20 & 9.48 & 1.127 & 41.74 & 8.53 \\
\hline \multirow{5}{*}{$\begin{array}{c}\overrightarrow{v_{0}} \\
\dot{0} \\
\overrightarrow{0}\end{array}$} & c POM & 31.56 & 1.42 & 22.23 & 192 & 5.74 & 1.51 \\
\hline & f POM & 25.15 & 1.43 & 18.56 & 75 & 2.24 & 0.60 \\
\hline & i $\mathrm{POM}$ & 29.05 & 1.52 & 19.12 & 218 & 6.53 & 1.73 \\
\hline & i silt + clay & 2.65 & 0.28 & 9.45 & 1.076 & 32.22 & 8.50 \\
\hline & f silt + clay & 2.1 & 0.21 & 9.95 & 1.635 & 48.94 & 12.75 \\
\hline
\end{tabular}

Concentration of $\mathrm{C}_{\mathrm{fr}}$, in both soils, is higher in light fractions - particulated organic matter compared with heavy fractions - OM associated with silt and clay. The concentrations of $\mathrm{C}_{\mathrm{fr}}$ in Pseudoglay come in following order $\mathrm{cPOM}>\mathrm{fPOM}>\mathrm{iPOM}>\mathrm{i}$ $\mathrm{s}+\mathrm{c}>\mathrm{f} \mathrm{s}+\mathrm{c}$. These results for Pseudoglay can be considered the opposite of the conclusions Golchin et al. (1994) who report that occluded within the micro aggregate light fraction (iPOM) had a higher concentration of $\mathrm{C}$ and $\mathrm{N}$ than the free light fraction (cPOM and $\mathrm{PPOM}$ ), what in generally confirmed results from Terra rossa.

$\mathrm{C}_{\mathrm{fr}} / \mathrm{N}_{\mathrm{fr}}$ ratio also show higher values in light fractions POM (less decomposed SOM) than in mineral associated OM which was actually a biochemical processed organic material, what is in accordance with studies John et al. (2004). The fraction particulated organic matter having a high $\mathrm{C} / \mathrm{N}$ ratio and low potential net mineralization of nitrogen $\left(\mathrm{N}_{\min }\right)$ (Catroux and Schnitzer, 1987; Chichester, 1969; Ford and Greenland, 1964; Sollins et al., 1984; Tiessen and Stewart, 1983; and Turchenek Oades, 1979 - according to J.Six et al., 2002).

The major part of the SOC in both soils was associated with the mineral fractions fs $+\mathrm{c}$ and is $+c$, in Pseudoglay $76 \%$ and in Terra rossa $81 \%$.

In Pseudoglay, absolute differences in SOC storage between forest and arable land is the most evident in fractions fs $+\mathrm{c}$ (difference $611 \mathrm{gC}_{\mathrm{fr}} \mathrm{m}^{-2}$ ) and is $+\mathrm{c}$ (difference $415 \mathrm{gC}_{\mathrm{fr}}$ $\mathrm{m}^{-2}$ ). Relative difference between arable and native soils is most the evident in the iPOM 
fraction where values of $\mathrm{C}_{\mathrm{fr}}$ storage in arable soil $\left(59 \mathrm{gC}_{\mathrm{fr}} \mathrm{m}^{-2}\right)$ is more than three times lesser than in grassland $\left(195 \mathrm{gC}_{\mathrm{fr}} \mathrm{m}^{-2}\right)$ and in fraction $\mathrm{cPOM}$ where is content of SOC in arable land halved. Six et al. 2002a in a study conducted at the Wildlife area in Ohio - USA, on the silty clay soil were found more than three times higher the amount of C in IPOM fraction in the forest ecosystem with walnut and oak than in agriculture. Many studies have found that the light fractions of particulate organic matter, particularly cPOM (> 250 microns), are relatively easily and widely decompose under cultivation indicating their relatively unprotected (biochemical and physical) status (Cambardela and Elliott, 1992; Six et al., 1999; Solomon al., 2000, according to Six et al., 2000).

In Terra rossa, SOC storage in all separated fractions has highest values in forest compared to arable land and grassland. Exceptions arei $\mathrm{s}+\mathrm{c}$ fraction where values $\mathrm{C}_{\mathrm{fr}}$ storage for forest and grassland are balanced, and fine POM fraction, which in all ecosystems have a similar values $\mathrm{C}_{\text {fr }}$ storage.

Table 5. The degree of stability of microaggregates (the percent of carbon from fraction intra microaggregates silt plus clay $(\mathrm{i} \mathrm{s}+\mathrm{c})$ in total chemically protected SOC associated with total silt and clay ( $\mathrm{f} s+\mathrm{c}$ plus i $\mathrm{s}+\mathrm{c}$ )

\begin{tabular}{|l|ccc|ccc|}
\hline & \multicolumn{3}{|c|}{ Pseudoglay } & \multicolumn{3}{c|}{ Terra rossa } \\
\hline $\begin{array}{l}\text { arable } \\
\text { land }\end{array}$ & grassland & forest & $\begin{array}{c}\text { arable } \\
\text { land }\end{array}$ & grassland & forest \\
\hline $\begin{array}{l}\mathbf{C}_{\text {fr- free silt+clay }}\left(\mathbf{g ~ m}^{-2}\right)\end{array}$ & 944 & 1587 & 1555 & 973 & 1127 & 1635 \\
\hline $\begin{array}{l}\mathbf{C}_{\text {fr- intra }} \\
\text { microaggregates } \\
\text { silt+clay (g m-2) }\end{array}$ & 477 & 695 & 767 & 661 & 1146 & 1076 \\
$\begin{array}{l}\text { \% C from } \\
\text { stable microaggregates }\end{array}$ & 34 & 30 & 33 & 40 & 50 & 40 \\
\hline
\end{tabular}

The share of carbon from fraction intra micro aggregate silt plus clay (i $\mathrm{s}+\mathrm{c})$ in the total chemically protected SOC associated with silt and clay ( $\mathrm{C}$ from $\mathrm{f} \mathrm{s}+\mathrm{c}$ plus i $\mathrm{s}+\mathrm{c}$ ) represents the degree of stability of microaggregates. Data show higher percent stable microaggregates in Terra rossa than in Pseudglay. Kemper Koch (1966) note that the stability of the aggregates increases to the maximum level with increase of clay content and the content of Fe-oxide (according to Six et al., 2002a).

\section{CONCLUSIONS}

In both types of soil, significantly lower storage of SOC within $30 \mathrm{~cm}$ on arable soils compared to forests (as well as to meadow in Pseudoglay) was recorded. The forest proved to be the most favorable for the accumulation of SOC in the form of organic matter both on the surface (O horizon) and in mineral soil. 
Mostly part of SOM in both soils is chemically protected by associated with silt and clay fractions. These values are for Pseudoglay with loam texture $76 \%$ and in Terra rossa with clayey loam texture $81 \%$. The degree of stability of microaggregates (the share $\mathrm{C}$ from intra silt + clay) is also higher on Terra rossa. It can connect with the present of Fe-oxides in the Terra rossa, which are connected with a positive impact on the stability of microaggregates (Kemper and Koch, 1966, according to Six et al., 2002). Furthermore, on acid topsoil of Pseudoglay were recorded low value CEC what can be connected with leeching bases, and it is well known a positive effect of $\mathrm{Ca}^{2+}$ (dominant in cation composition of CEC Terra rossa) on the aggregation.

In Pseudoglay, lower storage of $\mathrm{C}$ in arable soils related to natural ecosystems is evident in each separated fractions, spatially in iPOM and cPOM. Compared with Pseudoglay in Terra rossa different in SOC stocks between natural ecosystem and arable land in POM fractions is not so pronounced what indicated a good management with arable soils.

The example of managing agricultural soils on smaller farms (in private property) with cattle raising and agricultural production (Terra rossa) compared to large farms which was a big Agricultural Complex in state-owned (Pseudoglay), has shown that the way of managed with agricultural soil can significantly influence the trend of organic matter storage both in positive way (by decreasing cultivation, increasing the use of organic fertilizers, using different cultures in crop rotation; arable land on Terra rossa example) and in negative way (by intensive cultivation, fixed crop rotations, poor managing of manure; arable soil on Pseudoglay example). In Pseudoglay, by converting a abounded arable soil into a meadow, in the period of 17 years SOC storage within $30 \mathrm{~cm}$ became equal to the storage SOC in forest, while, compared to $50 \mathrm{~m}$ distant arable soil, $2.93 \mathrm{~kg}$ $\mathrm{m}^{-2}$ more SOC was accumulated in meadow. This is a good example that managing soil can increase storing $\mathrm{C}$ in soil, in other words, it shows what kind of positive effects can be produced by using mixture of clover-grass in crop rotation.

\section{LITERATURE:}

Bruce J. P., Frome M., Hattes E., Janzen H., Lal R., Paustian K., 1998, Carbon Sequestration in Soils - Workshop, Soil and Water Conservation Society, CalgaryAlberta,1988, 6-7.

Curtin D., Selles F., Wang H., Campbell C. A., I Biederbeck V. O., 1998, $\mathrm{CO}_{2}$ Emissions and Transformations of Soil Carbon and Nitrogen during Wheat Straw Decomposition, Soil.Sci.Am.J. 62:1035-1041 (1998).

Golchin A., J. A. Baldock, P. Clarke, T. Higashi and J. M. Oades, 1997, The effects of vegetation and burning on the chemical composition of soil organic matter of a volcanic ash soil as shown by ${ }^{13} \mathrm{C}$ NMR spectroscopy. II. Density fractions, Received 2 July 1996; accepted 28 November 1996.; Available online 5 June1998, science@direct. 
John B. M., 2003. Carbon turnover in aggregated soils determined by natural ${ }^{13} \mathrm{C}$ abundance, doktorska disertacija na Georg-August-Univerzitetu u Goettingenu, 4-18.

John B., Yamoshita T., Ludwig B., Flessa H., Storage of organic carbon in aggregate und density fractions of silty soils under different types and land use, available online at "http://www.sciencedirect.com" 2004, 1-2, 4.

Lal R., Grıffin M., Apt J., Lave L., Morgan M.G., 2004, Managing Soil Carbon, VOL 304, SCIENCE, www.sciencemag.org

Scheffer, F., Schachtschabel, P., 2002. Lehrbuch der Bodenkunde. 15st edition. Spektrum Akademischer Verlag, Heidelberg. 593 pp.

Six J., Callewaert P., Lenders S., De Gryze S., Morris S.J., Gregorich E. G.,.Paul E.A, I Paustian K., 2002a. Division S-7 - Forest and range soils; Measuring and Understanding Carbon Storage in Afforested Soils by physical Fractionation, Published in Soil Sci. Soc. Am J. 66:1981-1987 (2002a).

S1x J., Conant R. T., Paul E. A. I Paustıan K., 2002b, Stabilization mechanisms of soil organic matter: Implications for C-saturation of soils, Kluwer Academic Publishers, Plant and Soil 241: 155-176. 